\title{
Unpacking Academic Corruption in Zambia's Higher Education: Forms, Causes and Mitigation Measures
}

\author{
Alex Mugala1, Gift Masaiti' ${ }^{1}$ Kennedy Mwila $^{2 *}$ \\ ${ }^{1}$ Department of Educational Administration and Policy Studies, University of Zambia, Lusaka, Zambia \\ ${ }^{2}$ Graduate School of Education, Peking University, Beijing, China \\ Email: *mwilakennedy@yahoo.com
}

How to cite this paper: Mugala, A., Masaiti, G., \& Mwila, K. (2022). Unpacking Academic Corruption in Zambia's Higher Education: Forms, Causes and Mitigation Measures. Creative Education, 13, 55-74. https://doi.org/10.4236/ce.2022.131004

Received: December 8, 2021

Accepted: January 11, 2022

Published: January 14, 2022

Copyright $\odot 2022$ by author(s) and Scientific Research Publishing Inc. This work is licensed under the Creative Commons Attribution International License (CC BY 4.0).

http://creativecommons.org/licenses/by/4.0/

\begin{abstract}
Globally, Academic corruption is a superfluous issue that is largely jeopardizing the academic integrity of higher learning institutions. This research paper therefore sought to investigate the forms, causes and mitigation measures of academic corruption in a selected higher learning institution in Zambia. This paper employed an embedded mixed method design in which a questionnaire was administered to 400 students and interviews were conducted with 20 lecturers and administrators. Simple random sampling technique was used for students and typical case purposive sampling for lecturers and administrators. The findings do suggest that despite employing various mitigation measures, cases of academic corruption seem to be prevalent. Results showed that there was a higher prevalence of academic corruption among students, in particular, with respect to plagiarism and cheating which were notably cited as the two commonest forms of academic corruption among students. Among lecturers, professional misconduct, biased marking or grading were cited as the commonest forms of academic corruption. The findings further suggest that academic corruption is triggered by various causes such as peer pressure, performance anxiety and many others. As regards the mitigation measures, the research established that there are numerous measures that are employed to curtail academic corruption. Suspension, dismissal and expulsion were prominently cited as the most common measures that are employed to mitigate academic corruption. The study recommends among others the initialization of a policy on mandatory usage of plagiarism detection software, such as Safe Assign, Turnitin and Plagiarism Detect to curb the most common form of academic corruption among students.
\end{abstract}




\section{Keywords}

Academic Corruption, Forms, Causes, Mitigation Measures, Higher

Education Institution

\section{Background and Context}

Quayson (2013), Heyneman (2013) and Tagoe (2017) avow that academic corruption is a major concern in nearly all higher education systems across the globe. It is a complex phenomenon, which has become particularly evident within the academic arena involving all the stakeholders (Tagoe, 2017). Over the past two decades, academic corruption has increasingly been identified as a central impediment to educational development and national development in general. Academic corruption is pervasive, not only across contexts but over time. The issue of academic corruption has a detrimental effect on a college or university because it can damage the reputation of the institution. Globally, Academic Corruption remains prevalent despite concerted national efforts to fight the vice. While notable success has been achieved in eliminating corruption, academic corruption in higher learning institutions is still persistent, jeopardizing the teaching and learning process and compromising the quality of graduates. There is evidence that a larger number of students regularly engage in academic corruption (Tagoe, 2017). However, there is no clearly known evidence to prove the extent to which students cheat especially in the Zambian higher education terrain (Kerkvliet and Sigmund, 1999).

In adding her voice on academic corruption, Kirya (2019) argues that corruption in higher education is a growing global problem with grave implications for societies which take the form of political manipulation in university affairs. She further argues that other types of corruption include favouritism and nepotism in student admissions and staff appointments. A new form is also emerging focusing on corruption in licensing and accreditation, diversion of university or research funds, and even procurement fraud. In discussing the forms of academic dishonesty or corruption in higher education, Kirya (2019) stresses various forms which include plagiarism, essay mills, falsified research, examination fraud, and now growing trend of fake academic certificates across the globe. Sadly, it has also continuously been manifested through sexual exploitation, mainly between female students and faculty in higher education in what is commonly known as sextortion-where sex is the currency of bribe (Mwila, Lufungulo et al., 2021).

In some education institutions in Zambia, some lecturers have informally raised concerns about the increasing incidence of academic dishonesty among students. Although there is no doubt that academic dishonesty exists in Southern African universities, the extent of the problem is yet to be established (Akakandelwa et al., 2012). There is a perception, however, that educational institu- 
tions may be fighting a losing battle against academic corruption, given an environment of technological advancements that make it increasingly easier for students to access and misuse resources. Quayson (2013) avows that the rapid development of technology and the birth of "The digital child" as well as the emergence of new methods and techniques of cheating calls for collaborative efforts to mitigate or curb dishonest academic behavior due to its potential to not only deprive educators of the ability to carry out proper teaching and evaluation, but also to rob students of many learning opportunities in and outside classroom settings. Therefore, examining the forms, causes and mitigation measures of academic corruption will definitely help raise awareness as to the appropriate tactics and strategies needed to prevent it from becoming a norm on university campuses. Thus, this study intended to examine the forms, causes and mitigation measures of academic corruption in a selected higher learning institution in Zambia.

\section{Theoretical Underpinning and Selected Literature}

This paper on academic corruption is guided by the theory of planned behaviour. The theory of planned behavior was initially developed by Ajzen in 1991 . It can be used as a model for examining student's reasons to cheat (Sieman, 2009). The theory is based on the premise or notion that human beings are rational and they normally make decisions to engage in particular behaviours by weighting up possible costs against expectations of positive outcomes (Harding et al., 2007). This theory helps to provide an explanation to academic cheating as it reveals students' intentions through their attitudes towards cheating. These intentions precede behaviour and the greater the intention the more likely that an individual will engage in certain behaviour (Harding et al., 2007; Sieman, 2009).

As already alluded to, Academic corruption in education has been a problem in every country. It is particularly present at university and college levels. In fact almost all educational institutions have issues of academic corruption. According to Johnson (2012) corrupt acts are unethical; however not all unethical acts are corrupt. Corrupt acts in an educational setting are conducted by an individual that goes against the values that form a basis for educational processes. Another example is serious conduct that is considered criminal, actions of fraud, or the intentional breach of an individual's prescribed duty. As indicated, Academic corruption has occurred since the beginning of established colleges, especially in the US. Student cheating on essays has been found for at least 60 years (Michaels \& Miethe, 1989; Whitley Jr., 1998). Scholars warn that the level of cheating has become epidemic, citing several factors as to the reasons for cheating in colleges reported in the research (Robinson et al., 2004). Some of the reasons cited by these scholars are similar to the reasons highlighted by this study based on the Zambian scenario. Thus, it can be inferred that the reasons for engaging in academic corruption are seemingly the same in different countries.

Academic corruption is a serious problem affecting educational institutions, and therefore needs urgent attention. The need for further studies as well as this 
study, particularly in higher education institutions, is motivated by the fact that higher education is the ultimate level of education from where students are likely to directly enter the job market. Students' perceptions of what is institutionally acceptable and unacceptable regarding dishonest practices might therefore contribute to their behaviour at the workplace. In fact, students' inadequate understanding of what constitutes Academic corruption has been shown to correlate with the occurrence of unethical behaviours (Adedimeji, 2015). Hence, it is important to identify possible gaps between students' awareness and understanding of Academic corruption and what is stated in their institutional regulations. Unfortunately, the dearth of research data on Academic corruption, especially in sub-Saharan Africa, makes it difficult for higher education institutions leaders, policymakers and teaching staff to determine the effectiveness of available measures, and what might be needed to improve the existing plans. For example, in Ghana, no published work has explored the possible link between students' awareness and understanding of institutional policies and the likelihood to engage in academic misconduct (Johnson, 2012). Zambia is not an exception in this regard. In Zambia, there are no comprehensive studies highlighting the problem of academic corruption among lecturers and students. This notable gap makes this paper very imperative.

It is important for student affairs professionals or officers dealing with student affairs to understand why students choose to engage in cheating behaviours in the first place; for example, advances in technology have simply made it easier for students to plagiarize or purchase prewritten papers or exchange answers during exams through the use of cell phones (Boehm, Justice, \& Weeks, 2009; Hensley, 2013; Moeck, 2002). For some students, the appeal of being able to secure readily available work may be too good to pass up. Moreover, the pressure to achieve high grades also serves as a motivating factor for students to cheat. Moeck (2002) explained that many students may feel the need to obtain high grades to satisfy family members or to secure beneficial opportunities for themselves, and cheating may be viewed as a way to ensure that these grades are achieved. Relatedly, students with low Grade Point Average (GPA) tend to cheat more than those with high GPAs (Gerdeman, 2000; Hensley, 2013; Moeck, 2002; Wotring, 2007). Students with low GPAs may desire to achieve academically but do not understand how to do so in a beneficial and appropriate way, thus resulting in cheating. With the introduction of GPA in some higher education institutions in Zambia, there is a likelihood that some students might engage in academic corruption because of the desire to earn good grades and graduate with a desirable grade.

The inability for some students to manage their time effectively is another reason that cheating happens in college (Hensley, 2013). This study equally established that some students engage in academic corruption because they fail to manage their time effectively and fail to cope with the workload. Eventually, some engage in plagiarism, cheating and other forms of academic corruption in order to clear their courses. Many students procrastinate to the point that 
cheating may seem necessary in order to complete course assignments before deadlines. Others juggle so many obligations and responsibilities that the amount of time that they allot to spend on coursework does not allow them to give their work the attention it needs, and cheating allows them to get their work accomplished quicker. Of course, for students who perceive a class or assignment to be boring or unnecessary, cheating can allow them to invest relatively little effort into completing assignments (Gerdeman, 2000; Hensley, 2013). If students perceive lecturers as being uninterested in the courses they teach, this too increases the likelihood that cheating is utilized.

Technology has made the process of combating academic dishonesty more of a challenge for instructors; Owunwanne et al. (2010) found that $17 \%$ of students polled in recent studies reported that they used the Internet to take part in academic misconduct. In a study conducted by McCabe et al. (2006) at 23 public and private universities and colleges, $38 \%$ of undergraduate students admitted they had participated in Internet academic dishonesty by using the Internet to copy submitted classroom materials. Studies by Brown et al. (2010) revealed that $49 \%$ of students enrolled in undergraduate classes in the year 1988 were involved in academic misconduct. In the same course, $100 \%$ of the students polled in 2008 admitted to cheating on classroom assignments. Brown et al. (2010) reported that the Center for Academic Integrity discovered that nearly $80 \%$ of college students polled admitted to academic dishonesty on at least one occasion.

Jones (2011) discussed that $92 \%$ of the participants from his study revealed that they had or knew another student who had taken part in academic dishonesty. $41 \%$ of the participants indicated that their moral and ethical standing would prevent them from cheating in the classroom. This further revealed that $59 \%$ of the polled student body would participate in academic dishonesty. Student performance was the most documented reason that study participants gave for taking part in academic dishonesty. According to Jones (2011), the data compiled and evaluated in the study indicates a greater number of students felt that it was acceptable to take part in academic dishonesty. Olafson et al. (2014) discussed that in their study of 421 alleged academic misconduct forms from collegiate level students that plagiarism accounted for $49 \%$ of reported violations; $35 \%$ of the reports addressed students receiving outside help. There was also the finding that $91.5 \%$ of the reporting was by undergraduate level university students. The study found that academic dishonesty is widespread among college students, very few are caught, and fewer than that were ever sanctioned.

Mixon (1996) found that the determining factors of consistent academic dishonesty actions were very similar to other individuals who admitted to taking part in academic dishonesty on at least one occasion. The alternative is never committing academic dishonesty on any scholastic activity. Mixon (1996) reported that behavior consistent with academic dishonesty is inversely associated with Grade Point Average (GPA). However, cheating is related to the individual becoming acquainted with and observing other students who have taken part in academic dishonesty. He also found that student expectation of punishment 
handed down by a university also deterred student cheating. According to Mixon the belief that cheaters would receive swift and severe punishment leads to a decline in incidences of academic dishonesty.

\section{Statement of the Problem}

Despite being restrained from indulging in academically corrupt vices, some people in higher learning institutions still indulge in academic corruption (Davis, 2009). Jonathan (2018) indicates that some institutional administrators, faculty members and other stakeholders in higher learning institutions are involved in perpetual academically corrupt acts that are retrogressive, counter-productive and have got adverse effects on the academic goals of learning institutions. Though this scenario is common in higher learning institutions including those in Zambia, learners and educators have got a huge responsibility of ensuring that learning and assessments are administered in a credible manner. Adedimeji (2015) contends that the implications of academic corruption on society are severe and stark in the learning institutions. Institutions produce or graduate incompetent teachers who are "pushed" through higher institutions of learning, health personnel's that are not well trained, engineers who are void of quality and other mediocre professionals. These amateur experts are likely to dominate national horizons running and ruining the nation.

Dejectedly, other studies on academic dishonesty suggest that some educators even boast of academic papers that are heavily plagiarised (Adedimeji, 2015). Some students, with the active connivance of their parents, parade grades that were earned by "academic mercenaries" who were paid to sit for public exams on their behalf. Indisputably, the prevalence of cheating in learning institutions compromises the quality of education and holds lingering detrimental effects on students and society-at-large. If this situation continues and is left unchecked, it would have far reaching consequences and effects. It will have devastating effects on the quality of graduates and ruin the credibility and reputation of education and educators. Much more, it will hamper and retard national development. While studies have been done on academic corruption primarily focusing on the prevalence, seriousness and effects of academic corruption, in Zambia, it appears no empirical and theoretical study has been undertaken on the forms, causes and mitigation measures of academic corruption in higher learning institutions. Therefore, this paper examined the forms, causes, and mitigation measures of academic corruption in a selected higher learning institution in Zambia.

\section{Objectives}

1) To ascertain the common forms of academic corruption among students and lecturers in a selected higher learning institution in Zambia.

2) Investigate the causes of the most frequently occurring forms of academic corruption among students in a selected higher learning institution in Zambia.

3) Explore the mitigation measures have been employed to curtail academic 
corruption in a selected higher learning institution in Zambia.

\section{Methodology and Design}

As regards the methodological approach, the paper employed qualitative and quantitative research approaches in examining the forms, causes and mitigation measures of academic corruption. The Embedded Design was used for this study. Mwila (2016) states that Embedded Design is a mixed method design in which one data set provides a supportive, secondary role in a study based primarily on the other data type. The premises of this design are that a single data set is not sufficient, that different questions need to be answered, and that each type of question requires different types of data. The target population of this study encompassed students and lecturers of respective schools at the selected University. The sample size constituted 400 male and female senior students and 20 lecturers (10 males and 10 females from the respective schools) at the University. The researcher used simple random sampling to select respondents from the student populace. Conversely, respondents for the interviews were purposively sampled using typical case purposive sampling. With regards to the research instruments, quantitative data was collected using self-administered questionnaires which were administered to students. The questionnaire was segmented into distinct sections based on the objectives. Section A was entirely based on the social demographic characteristics, Section B was based on the Forms of Academic Corruption, Section C was based the Causes of Academic Corruption and the last section was anchored on the Mitigation Measures of Academic Corruption. For the collection of qualitative data, semi-structured interviews were carried out with Lecturers.

Before the actualization of data analysis, the data was edited for purposes of scrutinizing and identifying anomalies and later on rectifying them. Quantitative data was analysed using a prominent Computer Software called Statistical Package for Social Sciences (SPSS version 22) through descriptive and inferences. Thematic Analysis was used to analyse qualitative data. Thematic Analysis is a method for identifying, analyzing and reporting patterns within data.

The researchers opted to use thematic analysis because it provides a highly flexible approach that can be modified for the needs of many studies, providing a rich and detailed, yet complex account of data. The researchers took into consideration a number of ethical issues to ensure that participants were not harmed emotionally, physically, and psychologically. In addition, at every point during data collection, the researcher took time to briefly explain to participants, the aims of the study and its significance. Furthermore, knowing very well about the sensitive nature of the subject under investigation, the researchers took steps to assure participants of anonymity and confidentiality regarding the information they shared. Accordingly, the researcher did not coerce any participant at any time to participate in the study; participation was purely voluntary. Finally, the researchers sought for clearance from the Ethics Committee at the selected higher learning institution. 


\section{Results}

\section{Forms of Academic Corruption Common among Students}

Figure 1 shows that of academic corruption that was common among students, plagiarism was cited by $25.3 \%$ of the respondents as the commonest and most frequent form of Academic corruption at the institution. Plagiarism was followed by Cheating (19.9\%), Bribery (11\%), Fabrication and Falsification (8.10\%), Private tutoring (7.3\%), Abuse of academic materials (7.2), Disruptive behaviour (6.4\%), Misrepresenting (6.2\%), multiple submissions (4.5\%) and lastly, Complicity/Conspiracy/Collusion (4.1\%) which was cited as the least common form of Academic Corruption. These findings have been tabularized in the figure below.

Forms of Academic Corruption Common among Lecturers

Based on the information tabulated in Figure 2, Academic/Professional misconduct was cited by $27.8 \%$ of the respondents as the commonest form of

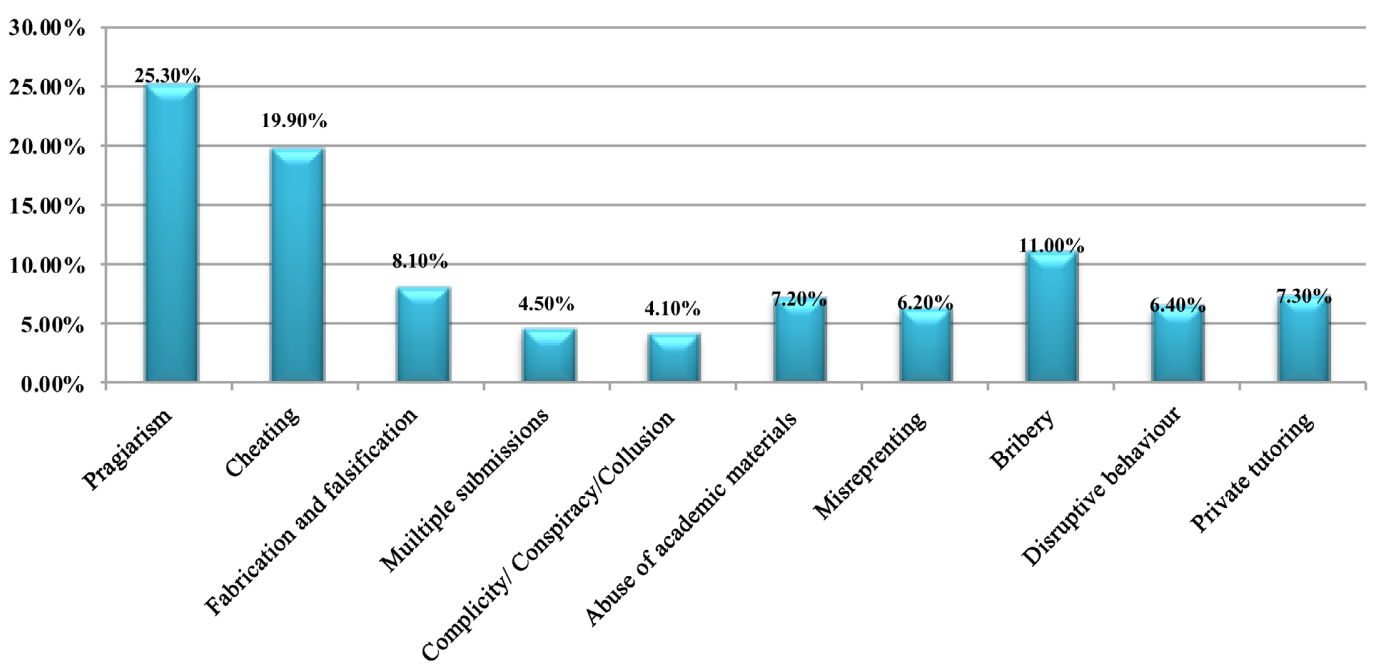

Figure 1. Responses of students on the forms of academic corruption common among students (source: Field Data, 2020).

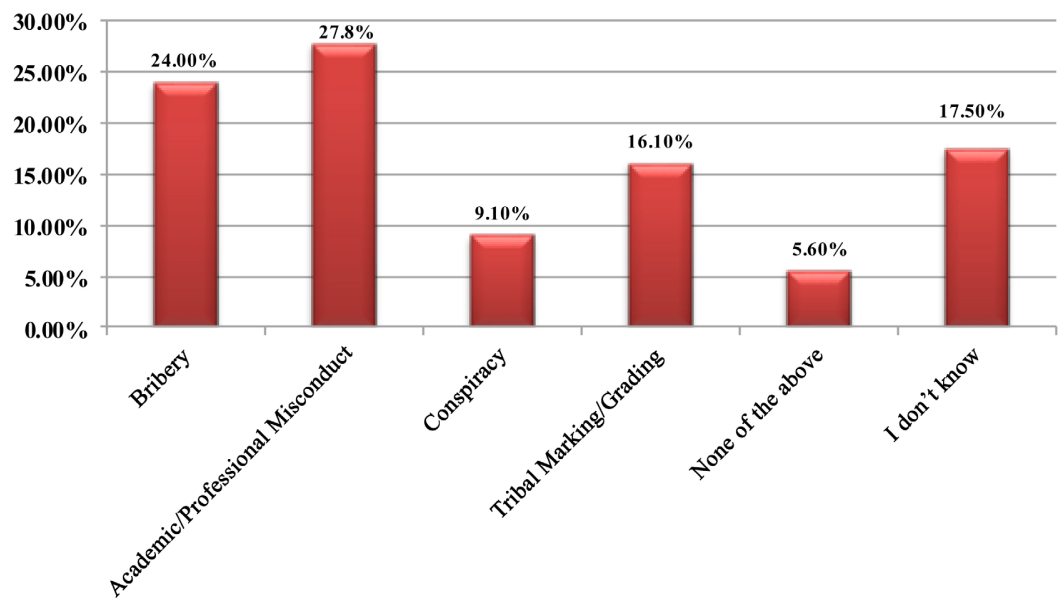

Figure 2. Response of students on the forms of academic corruption common among lecturers (source: Field Data, 2020). 
academic corruption among lecturers. It was preceded by Bribery (24\%), Tribal marking (16.1\%) and Conspiracy (9.1\%) which was cited as the least common form of academic corruption. 5.6\% of the respondents indicated that none of the aforementioned forms of academic corruption were prevalent among lecturers. $17.5 \%$ of the respondents indicated that they did not know the forms of academic corruption that are prevalent among lecturers.

\section{Causes of Academic Corruption among Students}

Figure 3 performance anxiety was cited by $16.3 \%$ of the respondents as the number one cause of academic corruption among students. The second common cause of academic corruption is failure to cope with workload (14\%). The third common cause of academic corruption is lack of research skills (11.9\%). The aforementioned causes are preceded by peer pressure (11.4\%), external pressure to succeed $(11.3 \%)$, self-justification habits $(9.6 \%)$, excuse making (7.4\%), situations that encourage academic dishonest (7.3\%), Lack of understanding about consequences $(6.3 \%)$, and lastly, unfamiliarity with what constitutes academic dishonesty (4.6\%).

Further, a Pearson's correlation was done to establish if there is a significant correlation between the causes of academic corruption and the objectivity of grades from lecturers (see results in Table 1). This was guided by both the null and alternative hypotheses which was stated as follows:

$H_{0}$ - There is a significant correlation between the causes of academic corruption and the objectivity of grades from lecturers.

$\mathrm{H}_{1}$ - There is no significant correlation between the causes of academic corruption and the objectivity of grades from lecturers.

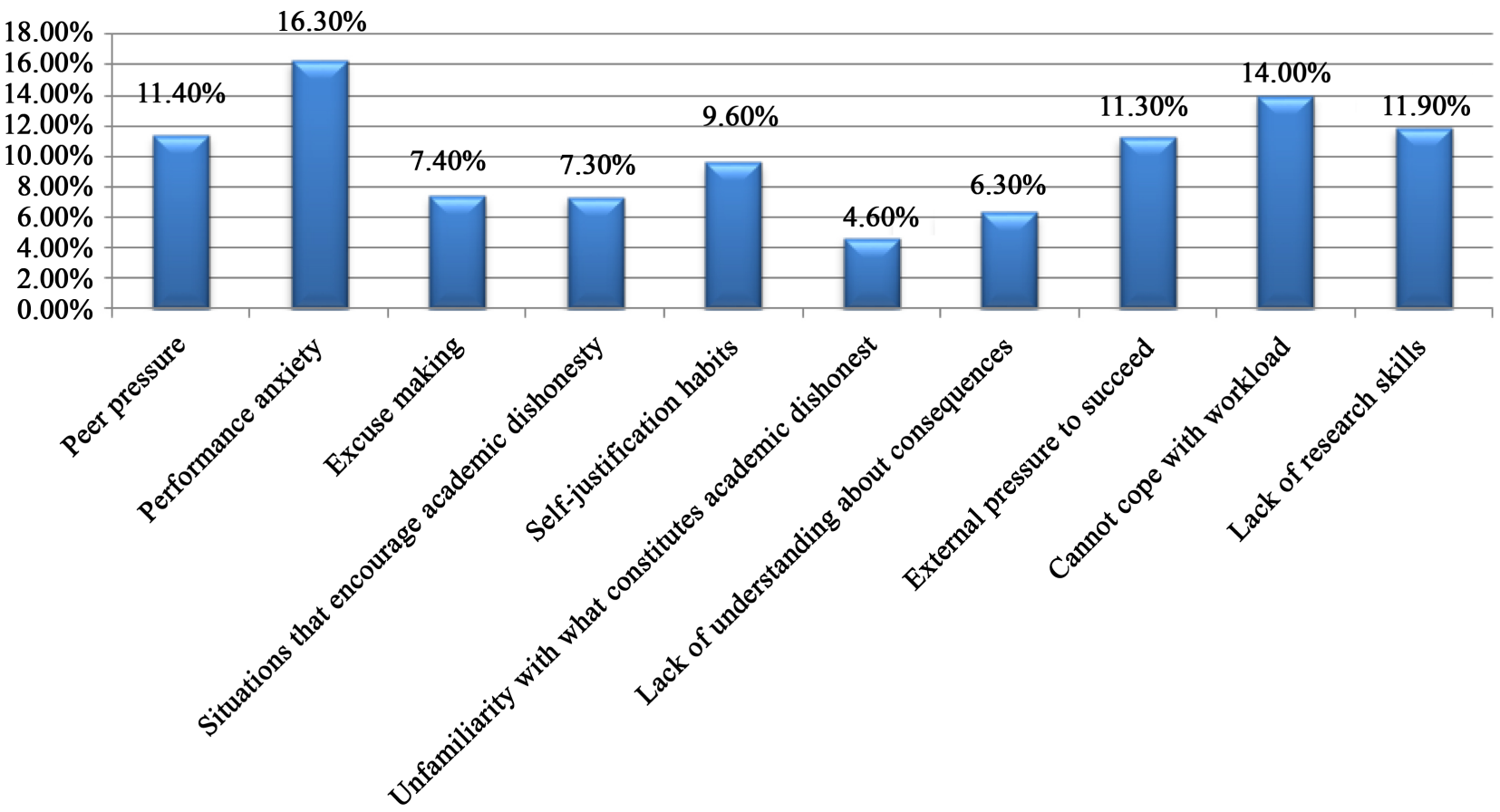

Figure 3. Responses of students on the causes of academic corruption among students (source: Field Data, 2020). 
Table 1. Pearson's correlation on correlation between the causes of academic corruption and the objectivity of grades from lecturers.

\begin{tabular}{|c|c|c|c|}
\hline & & $\begin{array}{c}\text { Causes of academic } \\
\text { corruption }\end{array}$ & $\begin{array}{l}\text { Objectivity of grades } \\
\text { from lecturers }\end{array}$ \\
\hline \multirow{3}{*}{$\begin{array}{l}\text { Causes of } \\
\text { academic } \\
\text { corruption }\end{array}$} & Pearson Correlation & 1 & 0.0039 \\
\hline & Sig. (2-tailed) & & 0.433 \\
\hline & $\mathrm{N}$ & 400 & 400 \\
\hline \multirow{3}{*}{$\begin{array}{l}\text { Objectivity of } \\
\text { grades from } \\
\text { lecturers }\end{array}$} & Pearson Correlation & 0.0039 & 1 \\
\hline & Sig. (2-tailed) & 0.433 & \\
\hline & $\mathrm{N}$ & 400 & 400 \\
\hline
\end{tabular}

Interpretation of results: Since the calculated $r$ value of 0.039 is less than the critical value of 0.05 at the chosen level of significance, the null hypothesis was accepted while the alternative hypothesis was rejected.

Decision: This is a positive correlation which means that there is a significant correlation between the causes of academic corruption and the objectivity of grades from lecturers. It was therefore concluded that there the causes of academic corruption were driven by the objectivity of earning good grades from lecturers.

\section{Causes of Academic Corruption among Lecturers}

The researcher was equally interested in knowing the causes of academic corruption among lecturers. Satisfaction of sexual desires, favouritism, monetary gain and failure to adhere to the code of ethics were cited as the causes of academic corruption among lecturers. Interviews with the lecturers revealed that some lecturers engage in certain forms of academic corruption because they want to satisfy their sexual desires. During the interviews, other lecturers pointed out that some lecturers engage in academic corruption because of their failure to adhere to the code of ethics. With reference to the causes of academic corruption, the following were some of the responses from the lecturers:

For me I think, some lecturers engage in academic corruption for monetary gain. Basically, it has do with someone not being satisfied with their monetary rewards earned formally. In some cases, dissatisfaction with monetary rewards can lead to providing an environment in which an individual begins to engage in illegal activities in order to raise some money. For others, if you look at academic corruption from the angle of favouritism, it might be a person trying to provide a favour or an illegal service to underserving student largely because of the relations that exists between the two (November, 2020).

Contrary, to the views above, one lecturer expounded:

Some lecturers indulge in tribal marking/grading and professional misconduct due to personal reasons. I wouldn't say because they are lacking and so they would want more money because even if a student would give a lec- 
turer money, I don't think it would be something substantial compared to what lecturers get and what a student would offer (November, 2020).

\section{Findings on the Mitigation Measures}

The study found that several measures have been employed to curtail or mitigate academic corruption. The mitigation measures that have been employed are shown in the figure below. Based on the findings in Figure 4 suspension was cited by $11.9 \%$ of the respondents as the commonest mitigation measure. This was preceded by expulsion/dismissal (11.8\%), plagiarism detection and verification of references (10.9\%), closer and much strict supervision during tests and examinations (9.3\%), promote transparency and access to information (8.1\%), give enough time to prepare for examinations, tests and assignments (6.9\%), sensitize tutors and lecturers on the evils of plagiarism (5.3\%), end impunity (3.8\%), motivate tutors and lecturers by increasing their wages $(2.1 \%)$ and lastly, stop over-enrolment $(1.8 \%)$.

Additionally, findings on mitigation measures, from the interviews were in line with the findings from the questionnaires. Findings from the interviews showed that suspension, expulsion, dismissal and giving enough time to prepare for examinations, tests and assignments are some of the most effective measures that have been put in place to mitigate academic corruption. Most of the

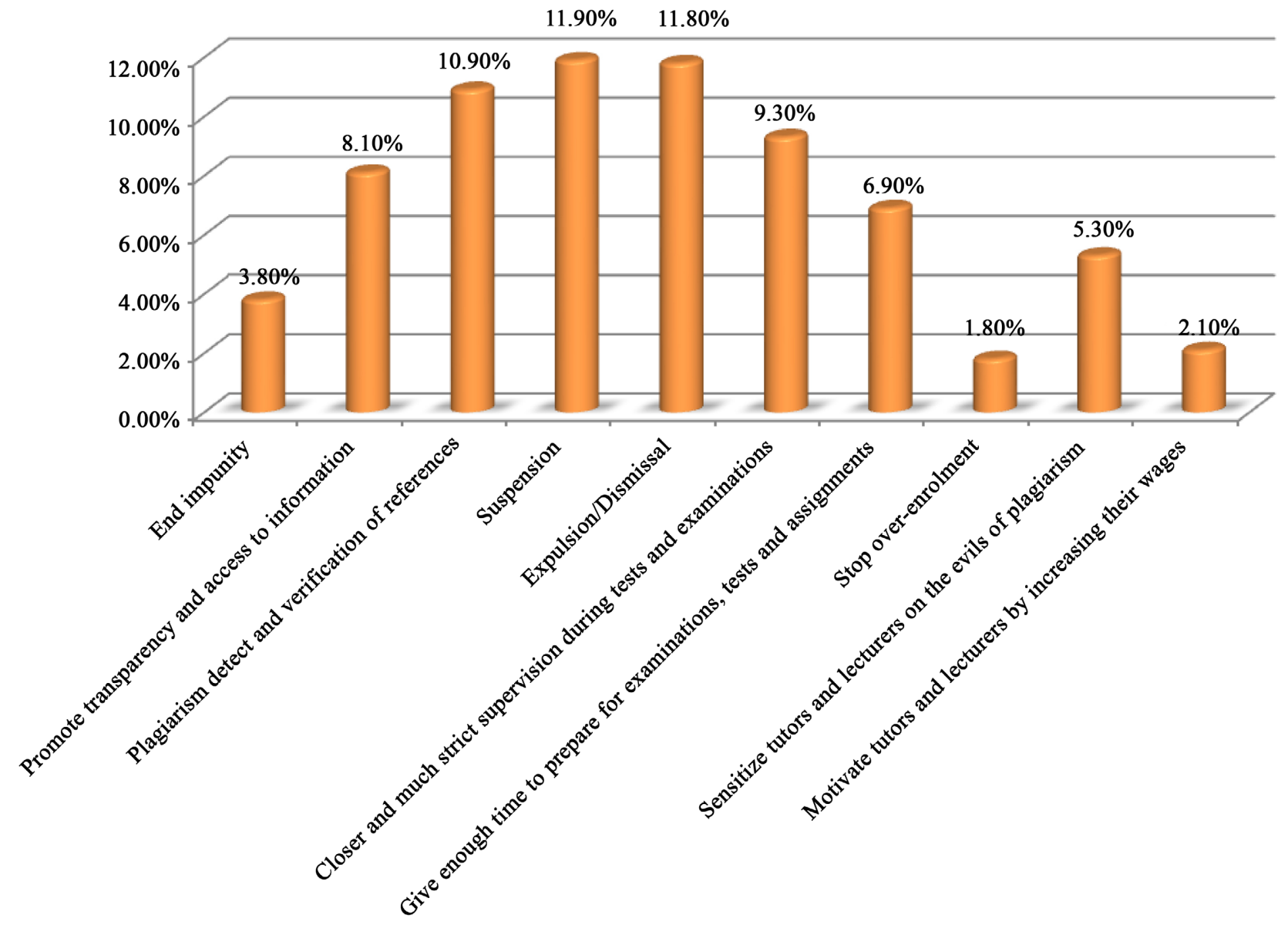

Figure 4. Responses of students regarding the mitigation measures (source: Field Data, 2020). 
respondents indicated that suspension, expulsion and dismissal have proved to be the most effective measures because they deter others from engaging in academically corrupt vices. Alluding to this, one of the Deans said: "Students and lecturers within the institution who are caught are sternly dealt with through suspension, dismissal or expulsion." The above response clearly entails that suspending, expelling and dismissing perpetrators can greatly help to alleviate or lessen academically corrupt vices in higher education institutions.

\section{Discussion}

\section{Forms of Academic Corruption}

This research paper revealed the fact that plagiarism is so existed among students in a Zambian higher education. In line with the findings of this paper, a study carried out by McCabe (2003), revealed that plagiarism is on the rise. The study findings further suggest that cheating was a common practice among students. Based on the findings, it was indicated and deduced that some students sneak in foreign materials in examination and test rooms, others try to access answers to questions using their mobile phones during tests and quizzes, copying from another test or exam and helping someone during a test. In view of the foregoing, numerous academic studies indicate that a significant number of students cheat on exams in university. Research presented in Eve and Bromley (1981), Haines et al. (1986), Genereux and McLeod (1995), Diekhoff et al. (1996) and McCabe, Butterfield and Trevino (2006) report that between 23 to 58 percent of student respondents admitted to cheating (mostly copying from, or sharing answers with, another student) on one or more major examinations during the prior academic year.

Further, the findings were indicative of the fact that faculty members engage in various forms of academic corruption. These findings support Morley's (2011) assertion that the most common form of professional misconduct on university campuses is "quid pro quo or sex-for-grades" since most male lecturers often feel they have the right to demand sexual favours from their female students. Furthermore, the findings corroborate with Houreld (2007) argument that male lecturers employ several strategies such as giving of low grades and witch hunting to trap their targets. Additionally, the findings further established that not all lecturers demand money to change grades; actually, some male lecturers request for sexual favours from female students in return for better grades and other favours.

Overall, the research findings confirm an average prevalence and eminence of various forms of academic corruption among students and lecturers. Compared to lecturers, students are found to engage more in various forms of academic corruption. Of particular concern is the high prevalence of bribery and plagiarism of work from both other students and formal sources. With respect to plagiarism, the findings of this study serve to support the prior literature and, importantly, the concerns of academics in terms of student attitudes toward pla- 
giarism and the ramifications for the assessment process and students' learning outcomes. The researcher suggest that university administrators need to examine this issue closely in order to develop mechanisms for managing and curtailing the level of academic corruption, since a failure to do so may lead to a further undermining of the academic integrity of the education system.

\section{Causes of Academic Corruption}

The findings from both the questionnaires and interviews were indicative of the fact that academic corruption is mostly triggered by peer pressure and performance anxiety. The study established and unearthed that students can pressure other students to commit acts of academic dishonesty in many ways. Secondly, anxiety about academic performance can cause some students to cheat in academic activities. Students may cheat to avoid failing a course or receiving a bad grade. Some students may use cheating as a way to cope with poor test-taking skills. Parents sometimes expect much from their children; perhaps, because of the family's reputation and the kind money they have invested in them. These expectations from parents and the pressure to do well in order to save the family's name were also identified as the other category of reasons why students engage in corrupt practices. The aforementioned findings are consistent with the findings of Moeck (2002) who explained that many students may feel the need to obtain high grades to satisfy family members or to secure beneficial opportunities for themselves, and cheating may be viewed as a way to ensure that these grades are achieved.

The findings further revealed that one of the most common reasons for academic dishonesty is students' inability to manage the pressures of their social and academic lives. Students who cannot plan and manage their workload and other activities and are usually behind in meeting their deadlines and can at times resort to cheating or plagiarism as an easy solution. These findings are supported by Hensley (2013) who elucidated that the inability for some students to manage their time effectively is another reason that cheating happens in university. Situations that encourage academic dishonesty were equally cited as a cause of academic corruption. When course policies do not spell out clearly what students can and cannot do, or when an instructor is not careful in enforcing academic integrity standards, some students may use the situation to commit acts of academic dishonesty. This finding is supported by Carter and Punyanunt-Carter (2006), who expounded that students were more likely to cheat on classroom examinations when they felt that faculty did not show an interest in curbing the cheating activity. Lastly, a Pearson's correlation was further done to establish if there is a significant correlation between the causes of academic corruption and the objectivity of grades from lecturers. The results indicated that there is a significant correlation between the causes of academic corruption and the objectivity of grades from lecturers. This entails that certain forms of academic corruption are triggered by the objectivity of grades from lecturers.

\section{Mitigation Measures that are Employed to Curtail Academic Corruption}

The paper also sought to establish the mitigation measures that are employed 
to curtail or mitigate academic corruption in higher learning institutions. The findings from both the questionnaires and interviews showed that there are numerous measures that are employed in an effort to mitigate academic corruption. Suspension, expulsion and dismissal were cited as some of the measures employed to mitigate academic corruption. Suspension was cited by $11.9 \%$ of the respondents as the commonest mitigation measure. This was preceded by expulsion/dismissal (11.8\%), plagiarism detection and verification of references (10.9\%), but evidence shows these measures are not effective in changing a student's conduct, and carry major long-term risks for their welfare. Instead of using these measures, universities can prevent academic dishonesty in their student bodies by promoting education on what constitutes academic dishonesty. Many students, as previous studies (McCabe, Trevino, \& Butterfield, 2001) have shown, are not necessarily aware of what it means to engage in academically dishonest behavior. Others know the behaviors all too well, but think that the risk of getting a better grade outweighs the slim chance of getting caught. Reviewing the university's handbook and policies regarding academic dishonesty during orientation or in various classes is one way to get the ball rolling toward integrity among students. Depending upon the seriousness of the offense, the student may also face being given a failing grade in the course, being removed from the course, receiving a written reprimand, disciplinary probation, suspension or expulsion. If the student has been accused of a more serious offense, he or she has the opportunity to seek counsel and fair hearing.

Additionally, the findings revealed that closer and much strict supervision of tests and examinations and plagiarism detection have been devised to discourage or mitigate academic corruption. To a certain extent, these measures have proved to be effective but perhaps the most effective way to reduce cheating is through education. Students who were educated about how to cite correctly and how to avoid plagiarism were caught plagiarizing significantly less than those who had not received any education (Belter \& du Pré, 2009). Whitley Jr. \& Keith-Spiegel (2001) outline the importance of establishing an academic dishonesty policy that is developed by students, clearly states what constitutes academic dishonesty, and addresses student, faculty, and administrator responsibilities as well as ways to resolve the problem.

In line with the findings of this study, Davis (1993) opines that along with giving students enough time to prepare for examinations, tests and assignments, another way to thwart academic dishonesty out of the university atmosphere is to require students to submit drafts of papers to be peer-reviewed. The peer-reviewed drafts are to be turned in with their final paper so lecturers have all the drafts and corrections while grading the final copy (Davis, 1993). This can serve as a way to prevent cheating or plagiarism on certain papers or essays by having students monitor and use evaluation. When exam time comes, lecturers have options and ways to prevent cheating. Administering different copies of the exam with the questions mixed up can prove to be very frustrating to students when they are expecting to copy from their "neighbour" (Strom \& 
Strom, 2007). Another way to simply change things up a bit is to change the wording of the questions on the test. It will become apparent on the student's faces when they act surprised that the questions have been changed or the wording is different from the test that they acquired from last semester (Strom \& Strom, 2007). In addition, some assignments and assessments can be tweaked in a way that makes it especially difficult to cheat. For instance, instead of using the same exam repeatedly during different semesters, lecturers can develop a pool of questions and randomly draw a limited number of questions from the pool each semester, or even for each testing attempt. Such little tricks can work well to fight cheating (Masaiti et al., 2021).

Similar to the findings and assertions of Stephens \& Wangaard (2009), this paper established that another important factor in guarding against academic dishonesty is to promote transparency and access to information and communicate to students by emphasizing the importance of mastery goals over performance goals. This way the students will focus on the content and mastering the content versus just working towards the overall outcome of their grade. Keeping mastery goals in mind and engaging students in the content they are learning is very appealing and interesting (Stephens \& Wangaard, 2009). When lecturers create appealing learning experiences, students apply their knowledge and apply the content learned to their lives. According to Stephens and Wangaard (2009), challenging students to have mastery goals is used as a tool to increase academic integrity.

Overall, academic dishonesty is a growing concern in our society, yet it can be challenging to overcome the barriers that impede learning. The promotion of academic integrity and mastery goals appears to serve as a significant factor for prevention of academic dishonesty. Through promoting integrity and mastery goals, and trying other classroom and individual interventions, a decline in academic dishonesty would be expected. Indeed, administrators and other relevant authorities within respective higher education institutions have a huge task and onus to put in place effective mitigation measures that will curtail and mitigate academic corruption. To make the discussion more conclusive, Table 2 below illustratively encapsulates the forms, causes and mitigation measures.

\section{Summary of the Forms, Causes and Mitigation Measures}

Table 2 shows the summery of the forms of academic corruption, their corresponding causes and suggested mitigation measures.

The Theory of Planned Behavior was employed parsimoniously in this study to investigate the forms and causes of academic corruption. The study's findings and the assumptions of the mentioned theory have a strong link. The current study takes into account opportunistic causes of cheating, which is in with the theory. Overall, the theory allowed the researchers to empirically examine the forms of academic corruption and its underlying causes. The current study, combined with the theory, suggests that relevant authorities should not wait until individuals in learning institutions act unethically before deterring, detecting, and punishing unethical behavior. 
Table 2. Summary of the forms, causes and mitigation measures.

\begin{tabular}{|c|c|c|}
\hline Form & Causes & Mitigation Measures \\
\hline Plagiarism & $\begin{array}{l}\text { Lack of research skills, } \\
\text { Failure to cope with } \\
\text { workload and } \\
\text { performance anxiety }\end{array}$ & $\begin{array}{c}\text { Plagiarism detection, } \\
\text { verification of references and } \\
\text { promoting transparency and } \\
\text { access to Information }\end{array}$ \\
\hline Cheating & $\begin{array}{c}\text { Peer pressure, performance } \\
\text { anxiety and self-justification } \\
\text { habits }\end{array}$ & $\begin{array}{l}\text { Suspension, Expulsion, } \\
\text { Strict supervision and } \\
\text { give enough time to prepare } \\
\text { tests and examinations }\end{array}$ \\
\hline $\begin{array}{l}\text { Fabrication and } \\
\text { Falsification }\end{array}$ & $\begin{array}{l}\text { Performance anxiety and } \\
\text { external pressure to succeed }\end{array}$ & $\begin{array}{l}\text { Promote transparency and } \\
\text { access to information }\end{array}$ \\
\hline Multiple Submission & $\begin{array}{l}\text { Peer pressure, external } \\
\text { pressure to succeed and } \\
\text { performance anxiety }\end{array}$ & $\begin{array}{l}\text { Promote transparency and } \\
\text { access to information }\end{array}$ \\
\hline Complicity & Performance anxiety & $\begin{array}{l}\text { Suspension and Strict } \\
\text { supervision }\end{array}$ \\
\hline $\begin{array}{l}\text { Abuse of academic } \\
\text { materials }\end{array}$ & $\begin{array}{l}\text { Lack of research skills } \\
\text { and unfamiliarity with } \\
\text { what constitutes } \\
\text { academic corruption }\end{array}$ & $\begin{array}{l}\text { Plagiarism detection } \\
\text { and sensitization }\end{array}$ \\
\hline Misrepresenting & Performance anxiety & Suspension \\
\hline Bribery & $\begin{array}{l}\text { External pressure to succeed } \\
\text { and performance anxiety }\end{array}$ & $\begin{array}{l}\text { Suspension, Expulsion } \\
\text { and Dismissal }\end{array}$ \\
\hline Disruptive behavior & Failure to cope with workload & Suspension and expulsion \\
\hline $\begin{array}{c}\text { Academic/Professional } \\
\text { Misconduct }\end{array}$ & $\begin{array}{l}\text { Monetary gain, Failure to } \\
\text { adhere to code of ethics and } \\
\text { Satisfaction of sexual desires }\end{array}$ & Suspension and Dismissal \\
\hline Conspiracy & $\begin{array}{l}\text { Monetary gain and failure to } \\
\text { adhere to code of ethics }\end{array}$ & Suspension and Dismissal \\
\hline Tribal Marking & Favouritism and Nepotism & Suspension and Dismissal \\
\hline
\end{tabular}

Source: Field Data, 2020.

\section{Conclusion}

The main objective of this research paper was to investigate the forms, causes and mitigation measures of academic corruption in a higher learning institution. The study was guided by three specific objectives. The first objective sought to identify the common forms of academic corruption among lecturers and students. The findings revealed that plagiarism is the commonest form of academic followed by cheating and bribery. Conversely, Academic/Professional misconduct was cited as the commonest form of academic corruption among lecturers followed by Tribal marking" and Conspiracy among others.

The second objective sought to ascertain the causes of academic corruption 
among lecturers and students in a higher learning institution. The findings were indicative of the fact that academic corruption among students is mostly triggered by performance anxiety. Further, according to the findings, the second common cause of academic corruption is a failure to cope with workload. The aforementioned causes of academic corruption were followed by other causes that have been discussed in this paper. Among lecturers, satisfaction of sexual desires, monetary gain and failure to adhere to the code of ethics were cited as the causes of academic corruption. Lastly, the third objective sought to establish the mitigation measures that are employed to curtail or mitigate academic corruption in higher learning institutions. Based on the findings, suspension was cited by most of the respondents as the commonest mitigation measure followed by expulsion/dismissal, plagiarism detection and verification of references, closer and much strict supervision during tests and examinations and other mitigation measures.

This research in line with other studies therefore, concludes that there is an indication of academic corruption in the institutions selected for this study, and it involved students and lecturers. The findings clearly show that academic corruption among lecturers is triggered by numerous reasons. Various measures have been employed in an effort to mitigate academic corruption among lecturers and students.

\section{Recommendations}

Based on the findings and the conclusion, the following recommendations are made:

1) Higher education institutions should institute a policy on the mandatory use plagiarism detection softwares, such as Safe Assign, Turnitin, Plagiarism Detect among others. Safe Assign is free for Blackboard users. These online resources enable users to compare their documents against other stored databases for plagiarism. Lecturers must also teach students how to use citation tools such as The Citation Generator and use the Internet to teach about plagiarism and how to avoid it.

2) Higher education institutions should institute appropriate disciplinary measures on any faculty member who engages in any form of academic corruption to serve as a deterrent to would be offenders.

3) Higher education institutions in Zambia should start using honour codes because it has proven to be an effective tool in the mitigation of academic corruption.

\section{Conflicts of Interest}

The authors declare no conflicts of interest regarding the publication of this paper.

\section{References}

Adedimeji, A. M. (2015). What Is Academic Corruption? https://mahfouzadedimeji.com 
Akakandelwa et al. (2012). Academic Dishonesty: A Comparative Study of Students of Library and Information Science in Botswana and Zambia. University of Botswana. https://doi.org/10.3172/JIE.22.2.137

Belter, R. W., \& du Pré, A. (2009). A Strategy to Reduce Plagiarism in an Undergraduate Course. Teaching of Psychology, 36, 257-261. https://doi.org/10.1080/00986280903173165

Boehm, P., Justice, M., \& Weeks, S. (2009). Promoting Academic Integrity in Higher Education. The Community College Enterprise, 13, 45-61.

Brown, B. S., Weible, R. J., \& Olmosk, K. E. (2010). Business School Deans on Student Academic Dishonesty: A Survey. College Student Journal, 44, 299-309.

Carter, S. L., \& Punyanunt-Carter, N. M. (2006). Acceptability of Treatments for Cheating in the College Classroom. Journal of Instructional Psychology, 33, 212-216.

Davis, F. (1993). Cheating in Schools. Wiley.

Davis, S. F. (2009). Cheating in School: What We Know and What We Can Do. Wiley Blackwell.

Diekhoff, G. M., LaBeff, E. E., Clark, R. E., Williams, L. E., Francis, B., \& Haines, V. J. (1996). College Cheating: Ten Years Later. Research in Higher Education, 37, 487-502. https://doi.org/10.1007/BF01730111

Eve, R. A., \& Bromley, D. G. (1981). Scholastic Dishonesty among College Undergraduates: Parallel Tests of Two Sociological Explanations. Youth \& Society, 13, 3-22. https://doi.org/10.1177/0044118X8101300101

Genereux, R. L., \& McLeod, B. A. (1995). Circumstances Surrounding Cheating: A Questionnaire Study of College Students. Research in Higher Education, 36, 687-704. https://doi.org/10.1007/BF02208251

Gerdeman, R. D. (2000). Academic Dishonesty and the Community College. ERIC Digest, ED447840.

Haines, V. J., Diekhoff, G. M., LaBeff, E. E., \& Clark, R. E. (1986). College Cheating: Immaturity, Lack of Commitment, and the Neutralizing Attitude. Research in Higher Education, 25, 342-354. https://doi.org/10.1007/BF00992130

Harding, T. D., Mayhew, M. J., Finelli, C. J., \& Carpenter, D. D. (2007). The Theory of Planned Behaviour as a Model of Academic Dishonesty in Engineering and Humanities Undergraduates. Ethics \& Behaviour, 17, 255-279. https://doi.org/10.1080/10508420701519239

Hensley, L. (2013). To Cheat or Not to Cheat: A Review with Implications for Practice. The Community College Enterprise, 19, 22-34.

Heyneman, S. (2013). Higher Education Institutions: Why They Matter and Why Corruption Puts Them at Risk. In Transparency International (Ed.), Global Corruption Report: Education. Routledge.

Houreld, K. (2007, March 25). Sexual Harassment Plagues Nigeria's Schools. Los Angeles Times.

Johnson, V. R. (2012). Higher Education, Corruption, and Reform. Contemporary Readings in Law and Social Justice, 4, 478-495.

Jonathan, M. (2018). Observing and Deterring Social Cheating on College Exams. International Journal for the Scholarship of Teaching and Learning, 12, Article 4. https://doi.org/10.20429/ijsotl.2018.120104

Jones, D. L. R. (2011). Academic Dishonesty: Are More Students Cheating? Business Communication Quarterly, 74, 141-150. https://debdavis.pbworks.com 
https://doi.org/10.1177/1080569911404059

Kerkvliet, J., \& Sigmund, L. C. (1999). Can We Control Cheating in the Classroom? The Journal of Economic Education, 30, 331-343.

https://doi.org/10.1080/00220489909596090

Kirya, M. (2019). Corruption in Universities: Paths to Integrity in the Higher Education Subsector.

https://www.u4.no/publications/corruption-in-universities-paths-to-integrity-in-the-hi gher-education-subsector

Masaiti, G., Mwila, K., Kulyambanino, C., \& Njobvu, T. (2021). Faculty Productivity in Zambian Higher Education in the Face of Internationalization: Unpacking Research, Publication and Citation at the University of Zambia. Scholarship of Teaching and Learning in the South, 5, 66-86. https://doi.org/10.36615/sotls.v5i1.153

McCabe, D. D., Trevino, L. K., \& Butterfield, K. D. (2001). Cheating in Academic Institutions: A Decade of Research. Ethics \& Behaviour, 11, 219-232. https://doi.org/10.1207/S15327019EB1103_2

McCabe, D. L., Butterfield, K. D., \& Treviño, L. K. (2006). Academic Dishonesty in Graduate Business Programs: Prevalence, Causes, and Proposed Action. Academy of Management Learning \& Education, 5, 294-305. https://doi.org/10.5465/amle.2006.22697018

McCabe, D. L. (2003). Some Good News about Academic Integrity. Change, 33, 32-38. https://doi.org/10.1176/pn.38.9.0032

Michaels, J. W., \& Miethe, T. D. (1989). Applying Theories of Deviance to Academic Cheating. MI.

Mixon, F. G. (1996). Crime in the Classroom: An Extension. Journal of Economic Education, 27, 195-200. https://doi.org/10.1080/00220485.1996.10844907

Moeck, P. (2002). Academic Dishonesty: Cheating among Community College Students. Community College Journal of Research and Practice, 26, 479-491. https://doi.org/10.1080/02776770290041846

Morley, L. (2011). Sex, Grades and Power in Higher Education in Ghana and Tanzania. Cambridge Journal of Education, 41, 101-115. https://doi.org/10.1080/0305764X.2010.549453

Mwila, K. (2016). Education and Skills Development: Examining the Effectiveness of Technical Education, Vocational and Entrepreneurship Training in Solwezi District, Zambia. Doctoral Dissertation, University of Zambia.

Mwila, K., Lufungulo, E. S., Masaiti, G., Mudenda, S., Kampamba, M., Mufwambi, W., Hikaambo, C. N. A. et al. (2021). Abolishment of Students' Meal Allowances at the University of Zambia: Exploring the Alternative Sources of Income, Challenges and Opportunities for First-Year Students. Creative Education, 12, 2733-2751. https://doi.org/10.4236/ce.2021.1211202

Olafson, L., Schraw, G., \& Kehrwald, N. (2014). Academic Dishonesty: Behaviors, Sanctions, and Retention of Adjudicated College Students. Journal of College Student Development, 55, 661-674. https://doi.org/10.1353/csd.2014.0066

Owunwanne, D., Rustagi, N., \& Dada, R. (2010). Students' Perceptions of Cheating and Plagiarism in Higher Institutions. Journal of College Teaching \& Learning, 7, 59-68. https://doi.org/10.19030/tlc.v7i11.253

Quayson, A. R. (2013). Forward in National Anti-Corruption Action Plan (NACAP). National Anti-Corruption Action Plan (2012-2021). Accra: NACAP.

Robinson, E., Amburgey, R., Swank, E., \& Faulkner, C. (2004). Test Cheating in a Rural 
College: Studying the Importance of Individual and Situational Factors. College Student Journal, 38, 380-395.

Sieman, A. S. (2009). Motivational Predictors of Academic Cheating among First-Year College Students: Goals, Expectations, and Costs. Dissertation, North Carolina State University.

Stephens, M., \& Wangaard, B. (2009). Using the Epidemic of Academic Dishonesty as an Opportunity for Character Education: A Three-Year Mixed Methods Study (with Mixed Results). Peabody Journal of Education, 88, 159-179.

https://doi.org/10.1080/0161956X.2013.775868

Strom, C., \& Strom, D. (2007). Cheating in Middle School and High School. The Educational Forum. https://doi.org/10.1080/00131720708984924

Tagoe, T. (2017). The Relationship between Emotional Intelligence and Job Satisfaction among Nurses in Accra. John Wiley \& Sons Ltd. https://doi.org/10.1002/nop2.70

Whitley Jr., B. E. (1998). Factors Associated with Cheating among College Students: A Review. Research in Higher Education, 39, 235-274. https://doi.org/10.1023/A:1018724900565

Whitley Jr., B. E., \& Keith-Spiegel, P. (2001). Academic Integrity as an Institutional Issue. Ethics \& Behavior, 11, 325-342. https://doi.org/10.1207/S15327019EB1103_9

Wotring, K. (2007). Cheating in the Community College: Generational Differences among Students and Implications for Faculty. Inquiry, 12, 5-13. 